\title{
Altering specific telomerase RNA template residues affects active site function
}

\author{
David Gilley, Margaret S. Lee, and Elizabeth H. Blackburn ${ }^{1}$ \\ Department of Microbiology and Immunology, Department of Biochemistry and Biophysics, University of California, \\ San Francisco, San Francisco, California 94143-0414 USA
}

\begin{abstract}
The ribonucleoprotein enzyme telomerase synthesizes telomeric DNA by copying a template sequence in the telomerase RNA. We studied the functional roles of specific residues in the Tetrahymena telomerase RNA template region. Unexpectedly, mutation of certain templating residues caused dramatic effects on specific aspects of the enzyme reaction, including loss of enzymatic fidelity and premature product dissociation. None of these fundamental changes in enzymatic action are explainable by altered base-pairing between the telomerase RNA and DNA substrate. These influences of specific template bases of the telomerase RNA on enzymatic properties of telomerase provide evidence for critical roles of these RNA residues in two active site functions-fidelity and DNA substrate/enzyme interaction.
\end{abstract}

[Key Words: Tetrahymena thermophila; telomerase RNA; template residues; enzymatic activity]

Received April 19, 1995; revised version accepted July 13, 1995.

Telomeres, the specialized structures comprising the termini of eukaryotic chromosomes, are essential for stable chromosome maintenance and the complete replication of linear chromosomal DNA, as well as having functions during critical developmental stages such as premeiotic homologous chromosomal interactions (for review, see Zakian 1989; Blackburn 1992, 1994). Telomeric DNA sequences are generally composed of short G-rich tandem repeats, running $5^{\prime} \rightarrow 3^{\prime}$ toward the distal end of the chromosome, although significant variations of this simple telomeric sequence motif have been found in some organisms (for review, see Blackburn 1994).

Cellular DNA polymerases can synthesize only in the $5^{\prime} \rightarrow 3^{\prime}$ direction, requiring an RNA primer to initiate synthesis. Without some form of terminal replicative mechanism, chromosomes would progressively recede from their ends, causing loss of telomere stabilizing functions and, ultimately, loss of essential coding regions (Watson 1972). Thus, the preservation of linear chromosomal termini requires a specialized cellular apparatus. Telomerase, a ribonucleoprotein (RNP) complex, is a specialized type of cellular reverse transcriptase that performs a critical role in chromosomal maintenance by adding telomeric sequence to chromosome ends, thus counterbalancing losses of terminal DNA from incomplete replication. Telomerase activity has been detected in extracts from several diverse eukaryotes (for review, see Blackburn 1992; Prowse et al. 1993; Mantell and Greider 1994; M. Cohn and E.H. Blackburn 1995)

${ }^{1}$ Corresponding author. and is apparently widespread. One exception is the fruitfly, Drosophila, which apparently relies on a retrotransposon mode of terminal chromosomal maintenance (Biessman et al. 1990; Levis et al. 1993).

It has been shown previously that specific nucleotides in the sequence $3^{\prime}$-AACCCCAAC-5', complementary to the TTGGGG telomere repeats of Tetrahymena thermophila, embedded within the 159-base telomerase RNA, function as templating residues for telomeric sequence synthesis in this organism (Yu et al. 1990). When introduced into Tetrahymena, mutant telomerase RNA genes with altered residues within the 3 '-AACCCCAAC-5' sequence caused the synthesis of the specifically altered telomeric repeats (Yu et al. 1990; Yu and Blackburn 1991). In addition, residues in the AACCCCAAC sequence that act as templating bases have been identified by in vitro reconstitution of telomerase activity, using mutated telomerase RNAs and partially purified protein fractions (Autexier and Greider 1994). These results supported the model proposed initially for telomere repeat synthesis by telomerase that was based on the sequence of the telomerase RNA and the elongation profiles of telomere and antisense primers adjacent to the templating region (see Fig. 1A; Greider and Blackburn 1989; Shippen-Lentz and Blackburn 1990). In the first step, the 3 ' nucleotides of the G-rich primer base-pair with the template region of the telomerase RNA (Fig. 1A-1). The G-rich primer is elongated, copying the telomerase RNA template, making first-round products (Fig. 1A-2). At the end of the telomerase RNA template region (position 43), the G-rich primer translocates and repositions for second-round synthesis (Fig. 1A-3). 
A

1) Base pairing

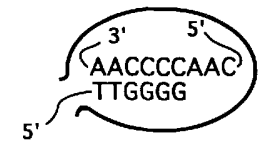

2) First round synthesis

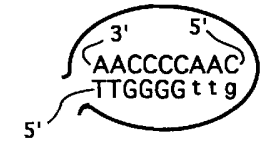

3) Translocation

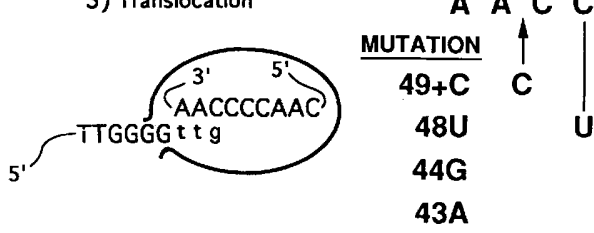

Figure 1. (A) Model for the addition of telomere repeats by telomerase (Greider and Blackburn 1989; Shippen-Lentz and Blackburn 1990). (1) 3' Nucleotides of the G-rich primer, $\left(\mathrm{T}_{2} \mathrm{G}_{4}\right)_{\mathrm{n}}$, base pair with the template region of the telomerase RNA. 3'-Terminal residues of the input primer are shown in uppercase letters. (2) The G-rich primer is elongated, copying the telomerase RNA template, making first-round products. Elongation products are shown in lowercase letters. (3) The G-rich primer translocates, repositioning for second-round synthesis. $(B)$ Telomerase RNA template nucleotides are shown in context to a schematic of the telomerase RNA secondary structure. Mutant telomerase RNA genes are designated by the telomerase RNA position followed by the altered nucleotide.

As has been defined for other polymerases, such as Escherichia coli DNA polymerase I (e.g., Beese et al. 1993), the active site of telomerase is that portion of the RNP responsible for binding the primer terminus of the DNA substrate and the dNTP substrate, and for carrying out catalysis of the reaction. Telomerase is an unusual reverse transcriptase because its RNA template is part of the larger telomerase RNA moiety that is an intrinsic part of the RNP. Ciliate telomerase RNAs have a highly conserved secondary structure outside the templating region as deduced both from phylogenetic covariation (Romero and Blackburn 1991; ten Dam et al. 1991; Lingner et al. 1994) and studies of the RNA conformation in solution (Bhattacharyya and Blackburn 1994). This conserved structure suggests that the telomerase RNA functions in other ways besides simple passive templating. Possible roles that could be envisaged for telomerase RNA include interactions with telomerase protein components or more direct participation of the RNA in active site functions of the enzyme. Because DNA synthesis involves copying the internal template, this portion of the telomerase RNA is necessarily in proximity to the active site.

Here we present the results of experiments in which we mutated specific RNA residues of Tetrahymena te- lomerase, allowed the mutated RNA to be assembled into the telomerase RNP complex in vivo, and examined its enzymatic properties in vitro. Our results identify striking base-specific effects of telomerase RNA residues on enzymatic fidelity and premature product dissociation that are not explainable by altered base-pairing between the telomerase RNA and DNA substrate. These results suggest that as well as providing a template, the telomerase RNA also contributes template residues to the enzyme active site, and that these residues play integral roles in basic active site functions.

\section{Results \\ Complete substitution of telomerase in vivo by mutant telomerase RNA}

Specific RNA residues of telomerase were mutated to establish their roles during telomeric repeat synthesis. Mutant telomerase RNA genes are designated by the telomerase RNA position followed by the altered nucleotide (Fig. 1B). To substitute telomerase in vivo with the mutated RNA, each altered telomerase RNA gene was inserted into the high copy number vector prD4-1 ( $Y u$ and Blackburn 1989; Yu et al. 1990) and introduced into cells by electroporation. The wild-type telomerase RNA genes of the recipient cells were still present at the normal $\sim 45$ copies per macronucleus, but Southern blotting showed that the mutant telomerase RNA genes were stably maintained on the high copy number vector at $>10^{4}$ copies per macronucleus. Thus, the mutant telomerase RNA gene was expected to be fully dominant over the endogenous wild-type gene ( $\mathrm{Yu}$ et al. 1990). The vast preponderance of the introduced mutant telomerase RNA over endogenous wild-type telomerase RNA was demonstrated in two ways: Particular mutants displayed cellular phenotypic dominance, eventually causing cell death, demonstrating that the endogenous wild-type telomerase RNA genes were not present at a sufficient level to phenotypically rescue transformed cells, and most directly, as described below, telomerase preparations from cells containing the mutated telomerase RNA gene were devoid of detectable wild-type enzyme activity.

Partially purified telomerase preparations were assayed in vitro using various conditions and DNA primers. The enzymatic reactions of the mutant and wildtype telomerases were compared by analyzing the patterns of reaction products fractionated on DNA sequencing gels. The in vivo effects of mutant 44G RNA, which contains a change at position 44 from an $A$ to a $G$ residue, were studied previously by introducing the telomerase RNA gene on the same high copy number vector, but using microinjection into the macronuclei of vegetatively growing cells (Yu et al. 1990), rather than electroporation during new macronuclear development as described in this paper (see Materials and methods). In the electroporation experiments a very early lethal cellular phenotype resulted from transformation, with cells typically dividing only about seven to nine times before 
cell division ceased. Because only a few hundred descendent cells were therefore produced from each $44 \mathrm{G}$ transformant, several hundred independent mutant transformant clonal lines were pooled to prepare sufficient telomerase for in vitro analysis of the mutant telomerase activity. Essentially complete substitution of the telomerase RNP by the RNA product of the mutant 44G telomerase RNA gene was clearly shown by the in vitro activity profile of the $44 \mathrm{G}$ mutant telomerase preparation isolated from transformed cells (Fig. 2). Products synthesized by the $44 \mathrm{G}$ mutant enzyme displayed characteristic banding patterns that were unique to the mutant enzyme and devoid of the wild-type banding pattern. This was shown first by supplying the mutant and wild-type enzyme preparations with a $\mathrm{G}_{4}$-ending primer $\left(\mathrm{T}_{2} \mathrm{G}_{4}\right)_{3}$ and $\left[\alpha^{-{ }^{32}} \mathrm{P}\right] \mathrm{TTP}$ only (other dNTPs were absent from this reaction). Wild-type enzyme, from untransformed cells or wild-type transformed (WT-t) transformants, added two $T$ residues to the $\mathrm{G}_{4}$-ending primer as expected (see schematic in Fig. 2A,B, lanes 1,2). In contrast, the $44 \mathrm{G}$ mutant enzyme preparation added only one $\mathrm{T}$ residue (Fig. 2B, lane 3). This was predicted because position 44 was changed from a $T$ to a $G$ residue (Fig. 2A). Even after long autoradiographic exposure there was no detectable contaminating wild-type enzyme background within the mutant enzyme preparation. Therefore, cells transfected with the $44 \mathrm{G}$ mutant telomerase RNA gene were devoid of detectable wildtype enzyme. This experiment also revealed that the 44G mutant enzyme does not form a rG/dT mispair at a detectable frequency by incorporating $\mathrm{dT}$ at the mutant position.

Previous work has shown that the $44 \mathrm{G}$ mutation caused synthesis of the predicted telomeric GGGGTC repeats in vivo (Yu et al. 1990; Yu and Blackburn 1991; Romero and Blackburn 1995). Direct demonstration that position 44 was used as a templating nucleotide in vitro came from several different experiments (Fig. 2C). With only $\left[\alpha-{ }^{32} \mathrm{P}\right] \mathrm{dGTP}$ and TTP, but no dCTP, in the reaction with mutant $44 \mathrm{G}$ enzyme, there was essentially no further addition after two nucleotides were added to a primer with a $G_{3}$ end, $T_{2} G_{4} T_{2} G_{3}$ (Fig. 2C, lane 9). This strong stop (Fig. 2C, lane 9) was at position 45 in the telomerase RNA, the position preceding position 44 . When ddCTP was added to the reaction, an extra band was observed corresponding to copying position 44 . (Fig. $2 \mathrm{C}$, lane 7). This band was shifted down relative to the corresponding band produced by wild-type enzyme, which incorporated the nucleotide $\mathrm{T}$ at that position (Fig. 2C, cf. lanes 7 and 8). This faster migrating species produced by the $44 \mathrm{G}$ mutant enzyme, and the lack of addition after position 44 , are both consistent with the addition of ddCTP at position 44 . With the $44 \mathrm{G}$ mutant enzyme, when dCTP was present in the reaction, there was a reproducible downward shift in the size of the product from copying position 44 , characteristic of the incorporation of a $\mathrm{C}$ instead of $\mathrm{T}$ at this position (Fig. 2C, lane 4). No doublet was observed at this position even after long autoradiographic exposures, which would have indicated incorporation of a $\mathrm{T}$ residue, had any wild-type

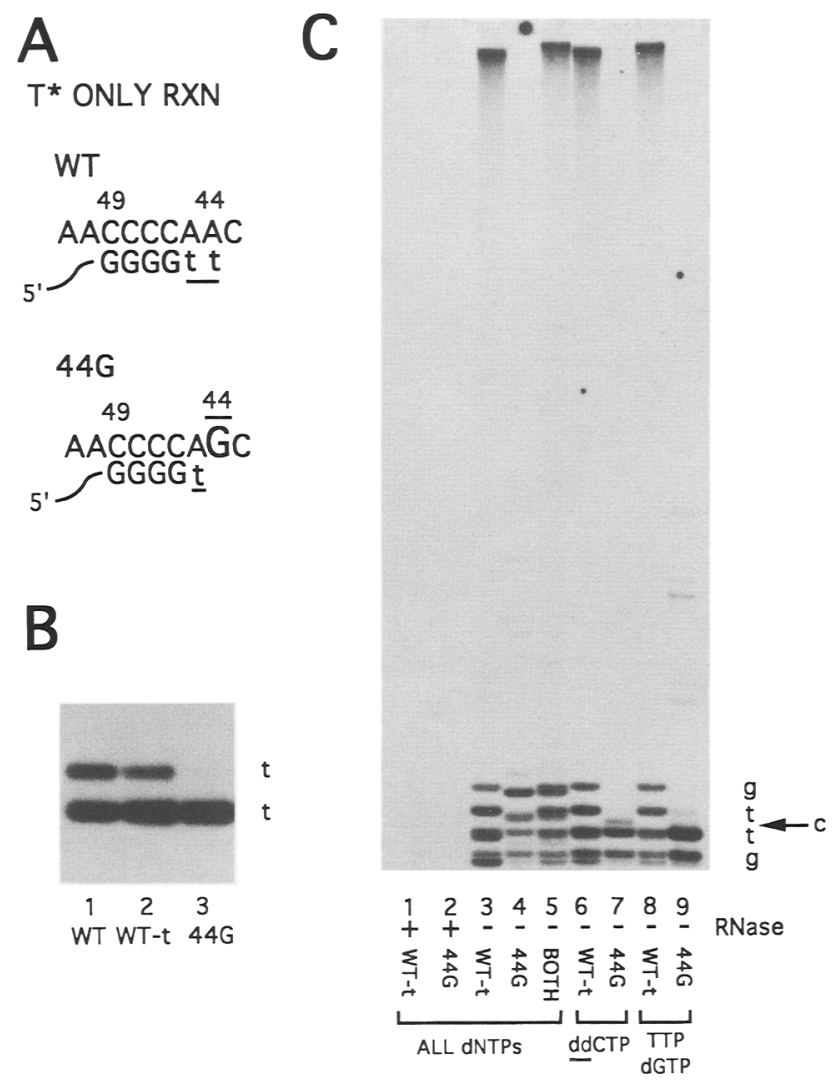

Figure 2. The $44 \mathrm{G}$ mutant enzyme dominates endogenous wild-type telomerase. $(A)$ Labeled $\left[\alpha^{-32} \mathrm{P}\right] \mathrm{TTP}$ only reaction $\left(\mathrm{T}^{*}\right.$ ONLY RXN) with primer $\left(\mathrm{T}_{2} \mathrm{G}_{4}\right)_{3}$. All other $\mathrm{dNTPs}$ were absent from the reaction. Schematic of wild-type and $44 \mathrm{G}$ template regions with the addition of two $\mathrm{T}$ residues and one $\mathrm{T}$ residue, respectively. Elongation products are shown in lowercase letters and underlined. $(B)$ Products of the $\left[\alpha^{-32} \mathrm{P}\right] \mathrm{TTP}$ only reaction separated on a $10 \%$ sequencing gel. All other dNTPS were absent from the reaction. (Lane 1) Wild-type telomerase (WT); (lane 2) telomerase isolated from cells transformed with the wild-type telomerase RNA gene inserted into the high copy number vector prD4-1 (WT-t); (lane 3) 44G mutant telomerase. (C) Telomerase reactions with primer $\mathrm{T}_{2} \mathrm{G}_{4} \mathrm{~T}_{2} \mathrm{G}_{3}$ separated on a $10 \%$ sequencing gel. (Lanes 1-5) all dNTPs-1.5 $\mu \mathrm{M}$ $\left[\alpha-{ }^{32} \mathrm{P}\right] \mathrm{dGTP}$ and $100 \mu \mathrm{M}$ of TTP, ATP and CTP; (lanes 6,7) 1.5 $\mu \mathrm{M}\left[\alpha-{ }^{32} \mathrm{P}\right] \mathrm{dGTP}$ and $100 \mu \mathrm{M}$ ddCTP; (lanes 8,9) $1.5 \mu \mathrm{M}[\alpha-$ ${ }^{32} \mathrm{P} / \mathrm{dGTP}$ and $100 \mu \mathrm{M}$ TTP. Lanes 1 and 2 were preincubated with RNase A; lanes $1,3,6$, and 8 contained WT-t telomerase; lanes $2,4,7$, and 9 contained $44 \mathrm{G}$ mutant telomerase; lane 5 contained a mixture of both WT-t and $44 \mathrm{G}$ telomerase.

activity been present. Elongation by the $44 \mathrm{G}$ enzyme proceeded only one nucleotide beyond position 44 , presumably to position 43 (Fig. 2C, lane 4). Wild-type telomerase products were unaffected by the presence or absence of dCTP or ddCTP (Fig. 2C, lanes 3 and 6, respectively). When wild-type and mutant $44 \mathrm{G}$ enzyme preparations were mixed together in the reaction, the short product patterns were additive and the formation of long products by the wild-type enzyme was not affected (Fig. 2C, lane 5). Hence, the reduced synthesis of 
long products by the mutant $44 \mathrm{G}$ enzyme was not caused by inhibition by a trans-acting inhibitor in the mutant enzyme preparation.

The lack of detectable wild-type telomerase activity in the 44G telomerase preparations is especially striking in the case of this particular mutant, because its effects on the cell were extremely deleterious to cell division, and hence any cells that lost the 44G mutant RNA gene would be expected to show a significant growth advantage. These results established that a mutant RNA expressed from the high copy prD4-1 vector can effectively completely substitute the telomerase RNP in vivo.

A mutation at templating position 43 causes premature product dissociation at position 45

The 43A mutant enzyme extended a primer ending in $G_{4},\left(T_{2} G_{4}\right)_{3}$, by the addition of three $T$ residues in the presence of $\left[\alpha-{ }^{32} \mathrm{P}\right]$ TTP but no other triphosphates (Fig. $3 \mathrm{~B}$, lane 1). In contrast, the wild-type enzyme added only the expected two $T$ residues /copying positions 45 and 44; Fig. 3B, lanes 2,3). Hence, we conclude that the $\mathrm{A}$ at position 43 is copied into a $\mathrm{T}$ by the $43 \mathrm{~A}$ mutant enzyme (Fig. 3A). Using telomerase activity reconstituted in vitro with a mutated $43 \mathrm{U}$ telomerase RNA, Autexier and Greider (1994) showed that an A residue is incorporated as expected if $43 \mathrm{U}$ is a template residue. In the presence of $\left[\alpha{ }^{32} \mathrm{P}\right] \mathrm{dGTP}$ and unlabeled TTP, the 43A mutant enzyme produced a seven-nucleotide repeat pattern (see spacing of asterisks in Fig. 3C, lanes 3, 5, 7, and 11). This is consistent with position 43 being used as a template, resulting in synthesis of $\mathrm{G}_{4} \mathrm{~T}_{3}$ repeats by the set of events shown schematically in Figure 3E: One $G$ residue, then three $T$ residues are added to the $G_{3} 3^{\prime}$ end of the primer $\left(\mathrm{GT}_{2} \mathrm{G}_{3}\right)_{3}$ (first-round synthesis; see Fig. 3E-2), the $\mathrm{T}_{3}$ ending first-round elongation product translocates and anneals to positions 50 and 51 and, possibly, 52 (Fig. $3 \mathrm{E}-3 \mid$, thereby positioning it to undergo another round of repeat addition, consisting of addition of seven nucleotides by copying positions 49-43 (second-round synthesis; Fig. 3E-4). Recently, we have found that wild-type and other mutant telomerases can use position 49 as a templating residue (D. Gilley and E. Blackburn, in prep.). The ability of a $T_{3}$-ending primer to be positioned for the production of elongation products by pairing with positions 50 and 51 was demonstrated with wild-type as well as $43 \mathrm{~A}$ mutant enzyme by including ddTTP instead of TTP in the reaction. Termination due to ddTTP incorporation was seen after the addition of five nucleotides to the input primer $\left(\mathrm{G}_{4} \mathrm{~T}_{3}\right)_{2}$, consistent with formation of the product $\left(\mathrm{G}_{4} \mathrm{~T}_{3}\right)_{2} \mathrm{gggg}(\mathrm{ddt})$ by copying positions $49-45$ (Fig. 3C, lanes 18,19). The 43A mutation also caused increased synthesis of products longer than this expected chain-termination product, suggesting translocated slippage synthesis of up to $5 \mathrm{dG}$ residues (lane 19). In addition, although the expected seven-nucleotide repeat was seen in the presence of $\mathrm{NaOAc}$, another unexpected property of the $43 \mathrm{~A}$ mutant enzyme was that in the absence of $\mathrm{NaOAc}$ an eight-nucleotide repeat pattern was produced after approximately three rounds of synthesis (Fig. 3C, lane 3).

With $\left[\alpha-{ }^{32} \mathrm{P}\right] \mathrm{dGTP}$ and unlabeled TTP, the mutant $43 \mathrm{~A}$ enzyme produced considerably shorter products than the wild-type enzyme (Fig. 3C, cf. WT-t lanes 2, 4, 6, and 14 with mutant $43 \mathrm{~A}$ lanes $3,5,7,15)$. Although the $G_{4} T_{3}$ repeat primer is efficiently elongated by the wild-type enzyme, it is possible that after translocation base-pairing of the mutant $T_{3}$-ending products synthesized by the $43 \mathrm{~A}$ mutant enzyme, as outlined in Figure $3 \mathrm{E}$, is less efficient than with the normal $\mathrm{T}_{2} \mathrm{G}$-ending elongation product.

DNA from cells transformed with the 43A mutant telomerase RNA gene hybridized in Southern blotting experiments specifically with the oligonucleotide $\left(\mathrm{G}_{4} \mathrm{~T}_{3}\right)_{2}$, whereas control wild-type DNA did not (data not shown). Therefore, position 43 is utilized both in vitro and in vivo in cells transformed with 43A mutant telomerase RNA gene.

Although the substitution of an A residue for the C normally at position 43 was anticipated to affect only the nucleotide incorporated by copying this templating position; unexpectedly, the elongation reaction was altered even before position 43 was reached. With the primer $\left(\mathrm{GT}_{2} \mathrm{G}_{3}\right)_{3},\left[\alpha^{-}{ }^{32} \mathrm{P}\right] \mathrm{dGTP}$ and cold TTP, the first nucleotide added by both $43 \mathrm{~A}$ and wild-type enzymes was a labeled $G$ from copying position 46 , producing a labeled 19-base product, followed by copying of positions $45-43$ in the first round of synthesis (Fig. 3C,D, lanes 2-11). However, with the 43A mutant enzyme, the product band corresponding to copying position 45 during this first round of synthesis (Fig. 3C,D, lanes $3,5,7$, position marked $P$ ) was much stronger than the counterpart band produced by the wild-type enzyme (Fig. 3C,D, lanes 2,4,6). The strong band produced at position 45 by the $43 \mathrm{~A}$ mutant enzyme was attributable to premature product dissociation from the enzyme because this product, like the next $\sim 35$ bands above it, was not chased into longer products, whereas higher molecular weight products were chased into longer products (Fig. 3C, lane 11). Product dissociation at position 45 was relatively minor during subsequent rounds of elongation with both the $43 \mathrm{~A}$ mutant and wild-type enzymes. This premature termination at position 45 by the $43 \mathrm{~A}$ mutant enzyme also occurred with the primer $\left(G_{3} T_{2} G\right)_{3}$ (Fig. 3C,D, lane 15). Therefore, although the number of primer nucleotides potentially able to base-pair with the template increased as product elongation proceeded along the template, termination occurred specifically at position 45 during the synthesis of these first round products. We tested whether raising the ionic strength by addition of $\mathrm{NaOAc}$, which would have been expected to increase the DNA-RNA hybrid stability, prevented this premature dissociation. However, this had the opposite effect: The premature termination at position 45 by the mutant $43 \mathrm{~A}$ enzyme increased as the ionic strength was raised (Fig. 3C, cf. lanes 3,5 , and 7). The premature termination product " $\mathrm{p}$ " now comprised $\sim 54 \%$ of the label in the total products (Fig. $3 \mathrm{C}$, lane 7 ). This corresponds to $\sim 67 \%$ of the product molecules, as the longer products are overrepresented in 
Gilley et al.

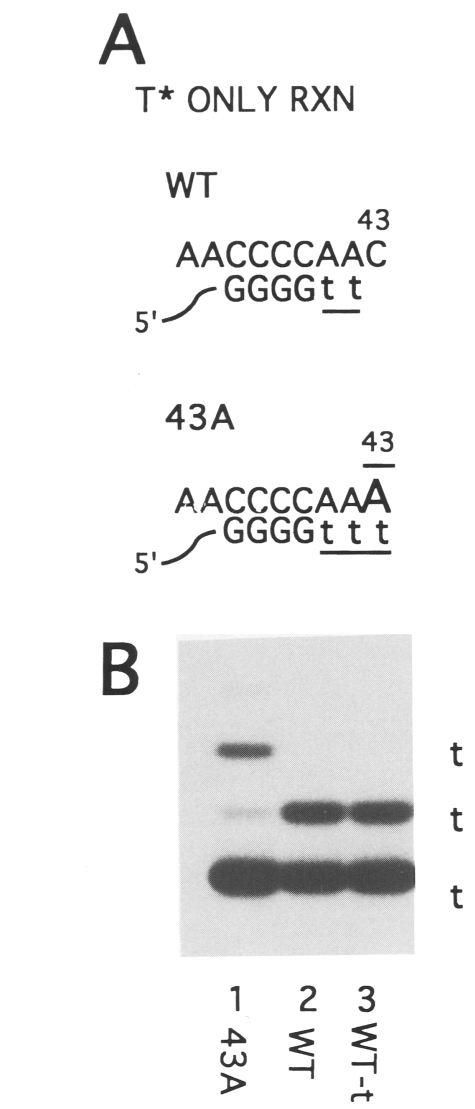

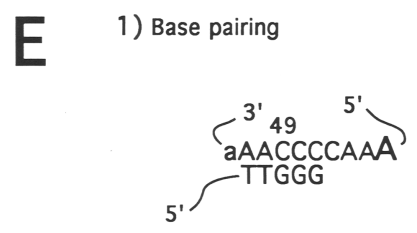

2) First round synthesis
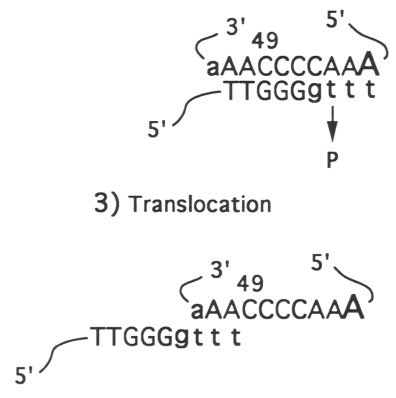

4) Second round synthesis

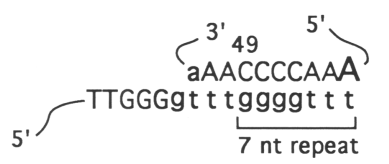

3) Translocation
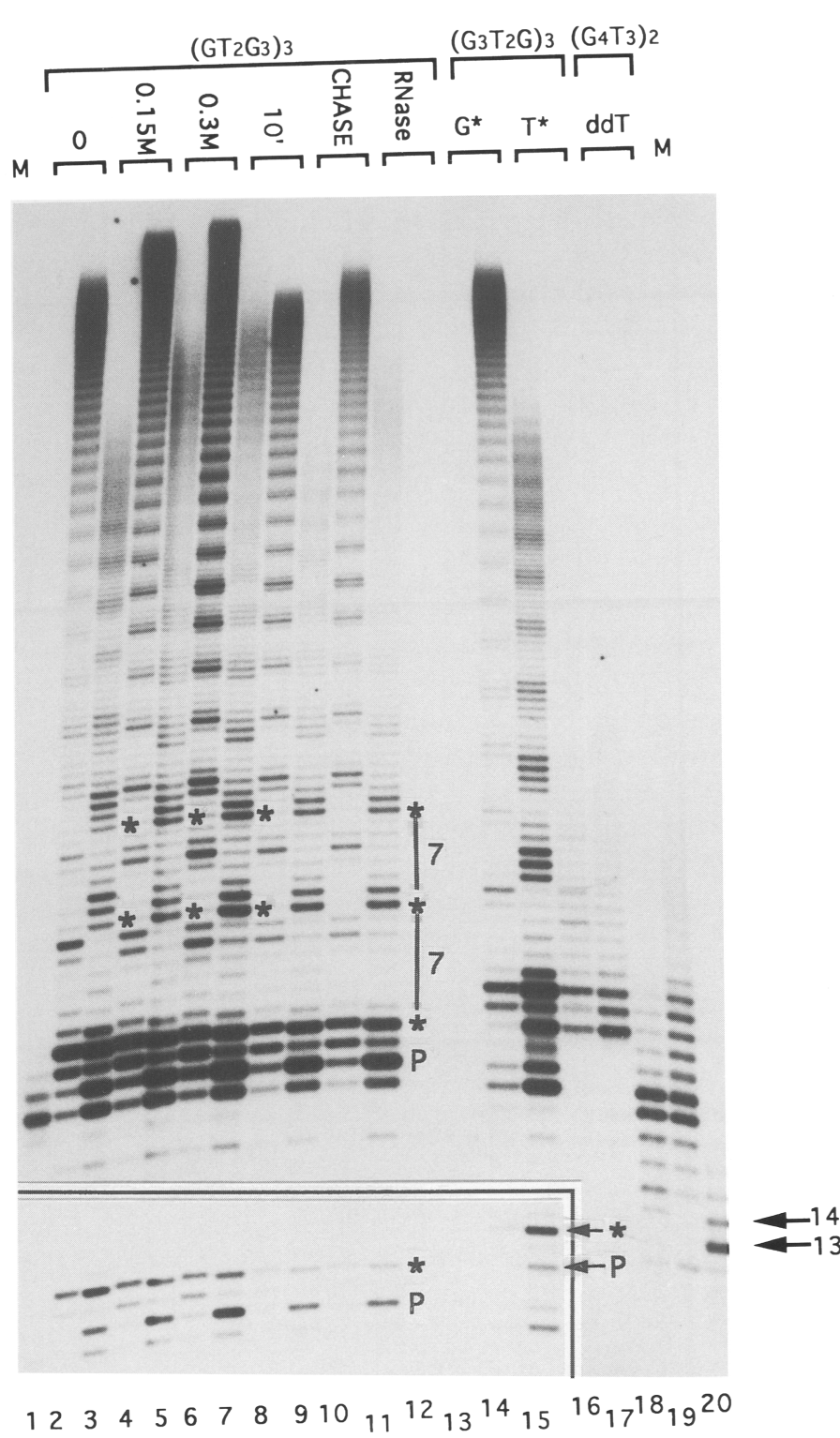

Figure 3. The 43A mutation causes early product dissociation at position 45 . $(A)\left[\alpha{ }^{-32} \mathrm{P}\right] \mathrm{TTP}$-only reaction ( $T^{*}$ ONLY RXN) with primer $\left(\mathrm{T}_{2} \mathrm{G}_{4}\right)_{3}$ (all other $\mathrm{dNTPs}$ were absent from the reaction). Schematic of wild-type and 43A template regions with the addition of two $T$ residues and three $T$ residues, respectively. Elongation products are shown in lowercase letters and underlined. $(B)$ Products of the labeled $\left[\alpha{ }^{32} \mathrm{P} \mid\right.$ TTP-only reaction with primer $\left(\mathrm{T}_{2} \mathrm{G}_{4}\right)_{3}$ separated on a $10 \%$ sequencing gel. All other dNTPs were absent from the reaction. (Lane 1) 43A mutant telomerase; (lane 2) wild-type telomerase $\langle\mathrm{WT}\rangle$; (lane 3) wild-type transformed telomerase (WT-t). (C) Telomerase reactions were separated on a $10 \%$ sequencing gel. Even-numbered lanes contained wild-type transformed enzyme; odd-numbered lanes contained 43A mutant enzyme. (Lane 1) Marker, major band corresponds to 19 nucleotides; (lanes 2-15) $1.5 \mu \mathrm{M}\left[\alpha^{-32}\right.$ P]dGTP and $100 \mu \mathrm{M}$ TTP. (Lanes 2,3) No

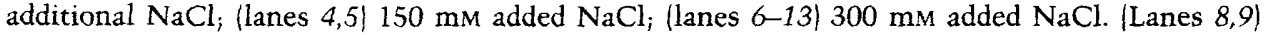
Reactions contained $300 \mathrm{~mm}$ added $\mathrm{NaCl}$ and were stopped after $10 \mathrm{~min}$; (lanes 10,11) reactions were brought to $100 \mu \mathrm{M}$ dGTP at $10 \mathrm{~min}$ and were continued for an additional $10 \mathrm{~min}$, containing $300 \mathrm{~mm} \mathrm{NaCl}$ throughout. Lanes 12 and 13 were performed under the same conditions as lanes 6 and 7 with prior incubation with RNase A. (Lanes 16,17) Reactions contained $1.5 \mu \mathrm{M}$ [ $\alpha^{-32} \mathrm{P}$ ]TTP and $100 \mu \mathrm{M}$ dGTP; (lanes 18,19$)$ reaction contained $1.5 \mu \mathrm{M}\left[\alpha^{-32} \mathrm{P}\right] \mathrm{GTP}$ and $100 \mu \mathrm{M}$ ddTTP; (lane 20) marker, major band corresponds to 13 nucleotides. (P) Early product dissociation at position 45 in the $43 \mathrm{~A}$ mutant enzyme lanes. Asterisks denote product dissociation at position 43 (note seven nucleotide spacing between asterisks in the 43A mutant enzyme lanes). (D) Lighter exposure of the lower portion of $C$. (E) Schematic of a model for first- and second-round synthesis with the $43 \mathrm{~A}$ mutant enzyme reacted with primer $\left(\mathrm{GT}_{2} \mathrm{G}_{3}\right)_{3}$. $(\mathrm{P}) \mathrm{Early}$ product dissociation at position 45 . Second and subsequent rounds of synthesis produce a seven nucleotide product. 
the autoradiograph because they contain multiple labeled dG residues (Lee and Blackburn 1993). With the wild-type enzyme, raising the ionic strength also modestly increased premature dissociation at position 44 (Fig. 3C, lanes 2,4,6), as observed previously (Lee et al. 1993).

These results revealed that substitution of $43 \mathrm{C}$ with an $\mathrm{A}$ causes strong premature product dissociation at position 45 , two nucleotides before the enzyme polymerization site reaches the altered RNA base at position 43 .

\section{A mutation in templating position 48 causes loss of fidelity and premature product dissociation at residue 45}

In previous work, one particular telomerase RNA mutation, a $\mathrm{C} \rightarrow \mathrm{U}$ mutation at position 48 in the telomerase RNA (see Fig. 1B), failed to cause synthesis of the expected mutant GAGGTT repeats in vivo. Instead, telomeric DNA was shortened, followed by cell death. This phenotype suggested that this mutation impaired telomerase activity in vivo by preventing telomere maintenance, which eventually led to cell death (Yu et al. 1990). Therefore, we analyzed the effect of the $48 \mathrm{U}$ mutation on telomerase enzymatic function in vitro. Several lines of evidence showed that in vitro, the $48 \mathrm{U}$ mutant enzyme incorporated dA by copying the mutant $r U$ residue. When the $48 \mathrm{U}$ mutant enzyme was assayed with the primer $\left(G_{4} T_{2}\right)_{3}$ in the presence of ddATP, a stop was seen at the second added nucleotide, corresponding to position 48 (see schematic, Fig. 4A; Fig. 4B, lane 1). This band showed the characteristic downward shift on the DNA sequencing gel indicative of incorporation of a dideoxy residue (top arrow in Fig. 4B, lane 1), compared with the corresponding elongation band with the wild-type enzyme (Fig. 4B, lane 2). In the presence of $\left[\alpha{ }^{32} \mathrm{P}\right] \mathrm{dATP}$ and unlabeled dGTP, TTP, and dCTP, with primer $\left(\mathrm{G}_{4} \mathrm{~T}_{2}\right)_{3}$, the $48 \mathrm{U}$ mutant enzyme incorporated the labeled $\mathrm{dA}$ at the expected position (the second elongation nucleotide; Fig. 4C, lanes 2,3). As expected, wild-type enzyme did not incorporate any detectable labeled dA residues (Fig. $4 \mathrm{C}$, lanes 5,6$)$. Therefore, position 48 was used as a templating nucleotide.

The $48 \mathrm{U}$ mutant telomerase exhibited two unprecedented properties. First, strong product dissociation was seen at position 45 , not only during the first but also in subsequent rounds of repeat addition (arrows in Fig. 4C, lanes $1-3$ ). This was only partly alleviated by increasing the dCTP, TTP, and dGTP concentrations to $100 \mu \mathrm{M}$ (Fig. $4 \mathrm{C}$, lane 3). The unusual dissociation at position 45 could explain the decreased amounts of longer products seen with the $48 \mathrm{U}$ mutant, because in contrast, the wildtype enzyme under the same conditions showed very little termination at position 45 (Fig. 4C, lane 4). Second, doublet and triplet bands were detected with the $48 \mathrm{U}$ enzyme during first-round synthesis with $100 \mu \mathrm{M}$ dATP, dCTP, TTP, and $1.5 \mu \mathrm{M}$ labeled dGTP (Fig. 4C, lane 1; Fig. 5A, lanes 4,7; Fig. 6, lanes 6,8). Because the DNA sequencing gels resolve on the basis of base composition as well as length, this indicated that misincorporation

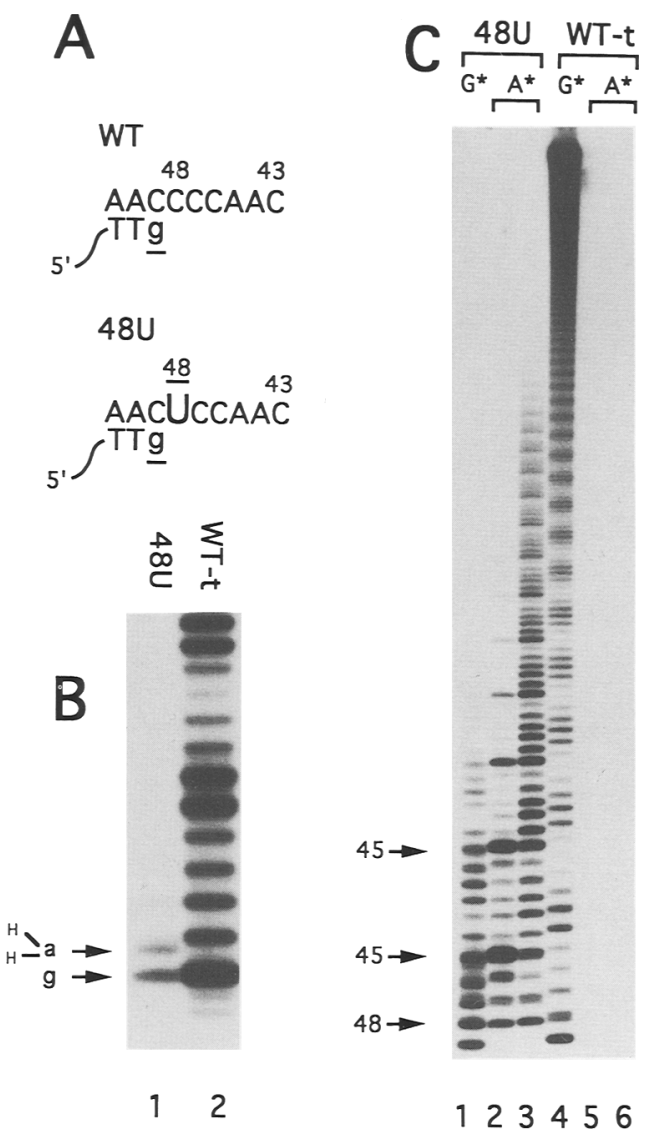

Figure 4. The $48 \mathrm{U}$ mutant telomerase has altered enzymatic properties. $(A)$ Schematic of wild-type and $48 \mathrm{U}$ telomerase RNA template regions with primer $\left(\mathrm{G}_{4} \mathrm{~T}_{2}\right)_{3}$ annealed. $(B)$ Telomerase products were separated on a $10 \%$ sequencing gel. Telomerase reactions contained $1.5 \mu \mathrm{M}\left[\alpha^{-32} \mathrm{P}\right] \mathrm{dGTP}, 100 \mu \mathrm{M}$ ddATP, $100 \mu \mathrm{M}$ TTP, and $100 \mu \mathrm{M}$ dCTP with primer $\left(\mathrm{G}_{4} \mathrm{~T}_{2}\right)_{3}$. (Lane 1) $48 \mathrm{U}$ telomerase; (lane 2) wild-type transformed telomerase (WT-t). Arrows denotes positions of ddATP and dGTP incorporation. (C) Telomerase reactions with primer $\left(\mathrm{G}_{4} \mathrm{~T}_{2}\right)_{3}$ separated on a $10 \%$ sequencing gel. (Lanes 1-3) Mutant $48 \mathrm{U}$ enzyme; lanes 4-6, wild-type transformed enzyme (WT-t). (Lanes 1,4) reactions contained $1.5 \mu \mathrm{M}\left[\alpha^{-32} \mathrm{P}\right] \mathrm{dGTP}, 100 \mu \mathrm{M}$ dATP, $100 \mu \mathrm{M}$ TTP, and $100 \mu \mathrm{M}$ dCTP; (lanes 2,5) reactions contained $1.5 \mu \mathrm{M}$ $\left[\alpha{ }^{-32} \mathrm{P}\right] \mathrm{dATP}, 1.5 \mu \mathrm{M}$ dGTP, $1.5 \mu \mathrm{M}$ TTP, and $1.5 \mu \mathrm{M}$ dCTP; (lanes 3,6$)$ reaction contained $1.5 \mu \mathrm{M}\left[\alpha^{-32} \mathrm{P}\right] \mathrm{dATP}, 100 \mu \mathrm{M}$ $\mathrm{dGTP}, 100 \mu \mathrm{M}$ TTP, and $100 \mu \mathrm{M}$ dCTP. Arrows denote positions 45 and 48.

occurred past the altered nucleotide at position 48 . Thus, in the presence of $100 \mu \mathrm{M}$ dATP, the $48 \mathrm{U}$ mutation greatly diminished fidelity of incorporation at positions 47 and 46, and possibly at other positions (Fig. 4C, cf. lanes 1 and 2). Decreasing the dATP concentration to 1.5 $\mu \mathrm{M}$ allowed longer products to form (Fig. 4C, lanes 2,3), although they were still much shorter than products produced by the wild-type enzyme (Fig. 4C, lane 4). Therefore, it appears that the products of misincorporation are elongated only poorly. These properties may explain why the predicted mutant repeats GAGGTT were not detectable in cells transformed with the $48 \mathrm{U}$ telomerase 
RNA, as determined by lack of hybridization with a (GAGGTT) ${ }_{2}$ probe (Yu et al. 1990; data not shown).

To determine which nucleotides were misincorporated to produce the doublet and triplet elongation bands, different mixtures of dNTPs were used in the reactions (Fig. 5A-C). Including only dATP in addition to dGTP and TTP was sufficient to produce all the misincorporation by the $48 \mathrm{U}$ mutant enzyme seen with all dNTPs present (Fig. 5A, lanes 4,7). Thus, misincorporated products were not detected when dATP was eliminated from the reaction (Fig. 5A, lanes 10,13), whereas elimination of dCTP had essentially no effect on the product profile (Fig. 5A, lane 7). Synthesis of essentially all products by the $48 \mathrm{U}$ mutant enzyme was sensitive to prior incubation with RNase A (Fig. 5A, lanes 1-3).

Direct evidence that $\mathrm{dA}$ residues were incorporated at positions 46 and 47 came from using the primer $\mathrm{G}_{2} \mathrm{~T}_{2} \mathrm{G}_{4} \mathrm{~T}_{2} \mathrm{GA}$ in the presence of only $\left[\alpha^{-32} \mathrm{P}\right] \mathrm{dATP}$ plus ddTTP (Fig. 5B,C). With the mutant $48 \mathrm{U}$ enzyme, but not the wild-type enzyme, three labeled bands were visible corresponding to the addition of 1,2 , and 3 nucleotides to the primer. Because the label was in $\left[\alpha^{-32} \mathrm{P}\right] \mathrm{dATP}$ and no other deoxynucleoside triphosphates were present, and incorporation of ddTTP would lead to chain termination, the labeled bands corresponding to addition of one nucleotide must correspond to incorpo-

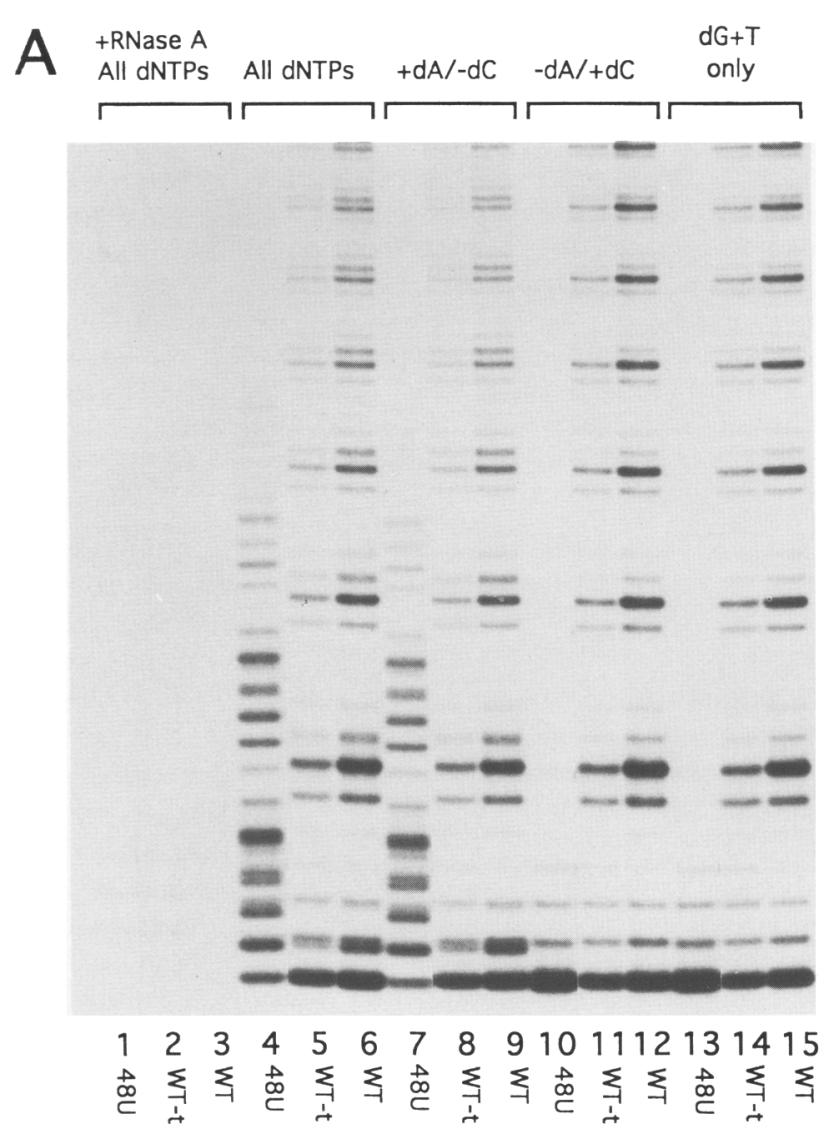

ration of $\mathrm{dA}$, and addition of the three nucleotides requires addition of minimally two contiguous dA residues. Hence, we propose that the three-nucleotide addition product is $G_{2} T_{2} G_{4} T_{2}$ GAaa(ddt) as shown in Figure $5 \mathrm{~B}$. We conclude that under these conditions the $48 \mathrm{U}$ enzyme misincorporates dA residues at a high frequency at the template $\mathrm{rC}$ residues at positions 47 and 46 . Relative to the wild-type enzyme assayed under identical conditions, we estimate conservatively that the rate of misincorporation of $\mathrm{dA}$ residues at these positions is elevated by at least 50 -fold in the presence of $100 \mu \mathrm{M}$ dATP (Fig. 5A; data not shown) and at least 20-fold in the presence of $4 \mu \mathrm{M}$ dATP (Fig. 5C).

Even at dATP concentrations low enough to minimize misincorporation, the $48 \mathrm{U}$ mutant failed to make products longer than $\sim 100$ nucleotides. It has been suggested that a second site or lagging product site on the telomerase RNP, other than the templating domain, interacts with $G_{4} T_{2}$ repeats at the $5^{\prime}$ region of the elongation products and is involved in positioning translocated products to allow processive synthesis of long products (Collins and Greider 1993; Lee et al. 1993). Therefore, we tested whether the $48 \mathrm{U}$ mutant fails to make long products because the mutant GAGGTT repeat products synthesized cannot interact properly with this proposed second site. If this were the case, with primers consisting of two

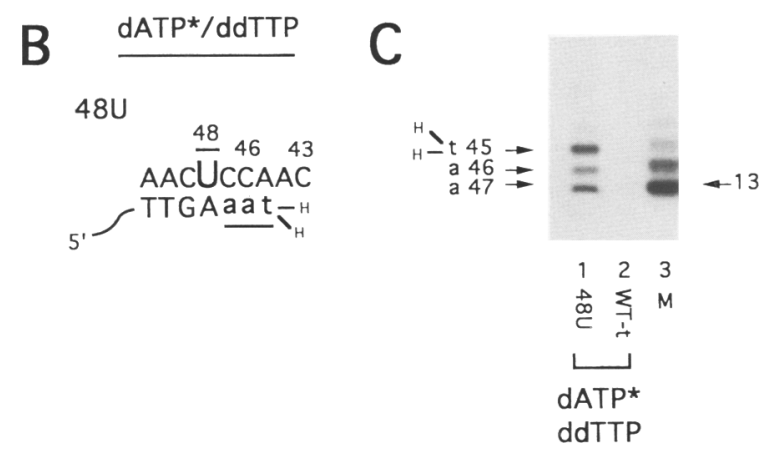

Figure 5. Misincorporation and early product dissociation by the $48 \mathrm{U}$ mutant telomerase. (A) Telomerase reactions contained primer $\left(\mathrm{G}_{4} \mathrm{~T}_{2}\right)_{3}$ with various combinations of dNTPs. Reaction products were separated on a $10 \%$ sequencing gel. (Lanes 1,4,7,10,13) 48U mutant enzyme; (lanes 2,5,8,11,14) wild-type transformed enzyme (WT-t); (lanes 3,6,9,12,15) wild-type enzyme. (Lanes 1-3) enzyme preincubated with RNase $A$ and reactions contained $1.5 \mu \mathrm{M}\left[\alpha^{-}{ }^{32} \mathrm{P}\right] \mathrm{dGTP}, 100 \mu \mathrm{M}$ dATP, $100 \mu \mathrm{M}$ TTP, and $100 \mu \mathrm{M}$ dCTP; (lanes 4-6) reactions contained $1.5 \mu \mathrm{M}\left[\alpha^{-32} \mathrm{P}\right] \mathrm{dGTP}, 100 \mu \mathrm{M}$ dATP, $100 \mu \mathrm{M}$ TTP, and $100 \mu \mathrm{M}$ dCTP; (lanes 7-9) reactions contained $1.5 \mu \mathrm{M}$ $\left[\alpha^{-32} \mathrm{P}\right] \mathrm{dGTP}, 100 \mu \mathrm{M}$ dATP, and $100 \mu \mathrm{M}$ TTP; (lanes 10-12) reactions contained $1.5 \mu \mathrm{M}\left[\alpha^{-32} \mathrm{P}\right] \mathrm{dGTP}, 100 \mu \mathrm{M}$ TTP, and 100 $\mu \mathrm{M} \mathrm{dCTP;} \mathrm{(lanes} \mathrm{13-15)} \mathrm{reactions} \mathrm{contained} 1.5 \mu \mathrm{M}$ $\left[\alpha^{-32} \mathrm{P}\right] \mathrm{dGTP}$ and $100 \mu \mathrm{M}$ TTP. (B) Schematic of the $48 \mathrm{U} \mathrm{mu}-$ tant template region with primer $G_{2} T_{2} G_{4} T_{2} G A$ annealed with the addition of two $\mathrm{dA}$ residues and a terminal ddT residue. Elongation products are shown in lowercase letters and underlined. (C) Telomerase reactions contained primer $\mathrm{G}_{2} \mathrm{~T}_{2} \mathrm{G}_{4} \mathrm{~T}_{2} \mathrm{GA}, 4.0 \mu \mathrm{M}\left[\alpha^{-}{ }^{32} \mathrm{P}\right] \mathrm{dATP}$ and $100 \mu \mathrm{M}$ ddTTP. (Lane 1) Mutant $48 \mathrm{U}$ enzyme; (lane 2) wild-type enzyme; (lane 3 ) marker, major band corresponds to 13 nucleotides. 
or three repeats of the predicted mutant sequence $\mathrm{GAG}_{2} \mathrm{~T}_{2}$, the wild-type telomerase would synthesize shorter elongation products than with wild-type sequence primers. However, with the wild-type enzyme, no significant differences in the amounts and length distributions of elongation products were seen between the 18-mer mutant primer $\left(\mathrm{GAG}_{2} \mathrm{~T}_{2}\right)_{3}$ and the 18-mer wildtype primer $\left(\mathrm{G}_{4} \mathrm{~T}_{2}\right)_{3}$ (Fig. 6, lanes 5,7). Moreover, with the 12-mer mutant primer, $\left(\mathrm{GAG}_{2} \mathrm{~T}_{2}\right)_{2}$, the ratio of long to short products was higher than with the corresponding wild-type primer $\left(\mathrm{G}_{4} \mathrm{~T}_{2}\right)_{2}$; i.e., more products were the result of the processive rather than the distributive mode of repeat synthesis (Fig. 6, lanes 1,3). Therefore, the wildtype enzyme readily made long products with $\mathrm{GAG}_{2} \mathrm{~T}_{2}$ repeat primers, despite their mispaired $3^{\prime}$ region and lack of wild-type $5^{\prime} G_{4} T_{2}$ repeats. Therefore, lack of synthesis of long products by the $48 \mathrm{U}$ mutant telomerases, seen

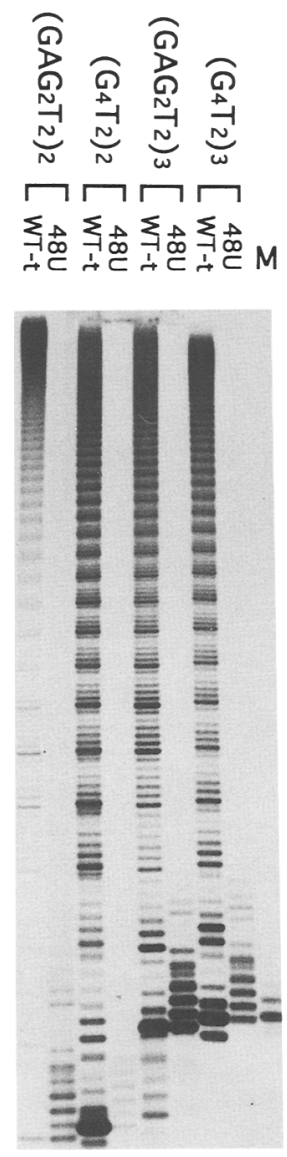

123456789

Figure 6. Reduced processivity by the $48 \mathrm{U}$ mutant enzyme is not attributable to altered second site interactions. Telomerase reaction contained $1.5 \mu \mathrm{M}\left[\alpha^{-32} \mathrm{P}\right] \mathrm{dGTP}, 100 \mu \mathrm{M}$ dATP, and 100 $\mu M$ TTP and were separated on a $10 \%$ sequencing gel. (Oddnumbered lanes) Wild-type enzyme; (even- numbered lanes) mutant $48 \mathrm{U}$ enzyme. (Lanes 1,2$)$ Primer $\left(\mathrm{GAG}_{2} \mathrm{~T}_{2}\right)_{2}$; (lanes 3,4) primer $\left(\mathrm{G}_{4} \mathrm{~T}_{2}\right)_{2} ; \quad$ (lanes 5,6$) \quad\left(\mathrm{GAG}_{2} \mathrm{~T}_{2}\right)_{3} ; \quad$ (lanes 7,8$)$ primer $\left(G_{4} T_{2}\right)_{3}$; (lane 9) marker, major band corresponds to 19 nucleotides. even when misincorporation rates by the $48 \mathrm{U}$ enzyme were minimal (with $1.5 \mu \mathrm{M}$ dATP; Fig. 4C, lanes 2,3), cannot be explained by lack of base-pairing between predicted mutant products and the template, or by poor interactions with the proposed second site. In contrast, the $48 \mathrm{U}$ mutant enzyme synthesized only short products when supplied with either $\mathrm{G}_{4} \mathrm{~T}_{2}$ or $\mathrm{GAG}_{2} \mathrm{~T}_{2}$ repeat primers (Fig. 6, lanes 6,8). With this mutant enzyme, higher synthesis occurred with the $\mathrm{GAG}_{2} \mathrm{~T}_{2}$ repeat primers than with the $G_{4} T_{2}$ repeat primers, suggesting that the matched Watson-Crick base-pairing of the $3^{\prime}$ end of the $\mathrm{GAG}_{2} \mathrm{~T}_{2}$ repeat primers with the mutant $48 \mathrm{U}$ template sequence increased their priming efficiency (Fig. 6, cf. lanes 3 and 7 with lanes 4 and 8 ).

In summary, the $48 \mathrm{U}$ mutation in telomerase RNA not only caused the expected incorporation of dA by copying the $\mathrm{rU}$ at position 48 , but also had profound effects on the enzyme's mode of polymerization, including premature, specific dissociation of the product at position 45 and a severe loss of fidelity when copying positions 47 and 46 .

\section{An additional $C$ residue in the template region causes loss of fidelity and decreased processivity}

We analyzed a mutant telomerase, here designated as $49+\mathrm{C}$, containing a run of five cytosine residues instead of four cytosines normally at positions $49-46$ in the RNA template domain (Fig. 7B). In previous work using transformation by microinjection, this mutant telomerase RNA gene (called pTER3 previously) caused the in vivo synthesis not only of $G_{5} T_{2}$ repeats but also of repeats containing variable numbers of $G$ residues $\left(G_{6} T_{2}\right.$, $\mathrm{G}_{7} \mathrm{~T}_{2}$, and $\mathrm{G}_{8} \mathrm{~T}_{2} ; \mathrm{Yu}$ and Blackburn 1991). When the mutant $49+C$ enzyme from cells transformed by electroporation was assayed in vitro with a $\left(\mathrm{GT}_{2} \mathrm{G}_{3}\right)_{3}$ primer, it produced a clear seven nucleotide repeat pattern in the second and third rounds of synthesis, consistent with production of a $G_{5} T_{2}$ repeat (Fig. 7A, lane 2; see schematic Fig. 7B). However, the mutant $49+\mathrm{C}$ enzyme failed to make products longer than 100 nucleotides (Fig. $7 \mathrm{~A}$, cf. lanes 1,21 . This absence of long product production cannot be explained by mismatching of the mutant products to the template region, since products produced by this mutant enzyme should be able to base-pair with the templating domain after translocation (see Fig. 7B).

A dramatically altered enzymatic fidelity was apparent when the mutant $49+C$ enzyme was assayed with $\left[\alpha-{ }^{32} \mathrm{P}\right] \mathrm{dGTP}$ and ddTTP. Unlike the wild-type enzyme, which terminated precisely at the predicted second addition position (Fig. 5A, lane 3), under identical conditions this mutant enzyme did not terminate, but instead synthesized poly(dG) tracts of up to $\sim 30$ nucleotides (Fig. $5 A$, lane 4). This lack of fidelity of the mutant $49+C$ enzyme resembles, in a more extreme form, the in vivo results with this mutant enzyme (Yu and Blackburn 1991). Therefore, addition of the single $C$ residue to the templating region of the telomerase RNA resulted in extensive alteration in templating fidelity in vitro. 
Gilley et al.

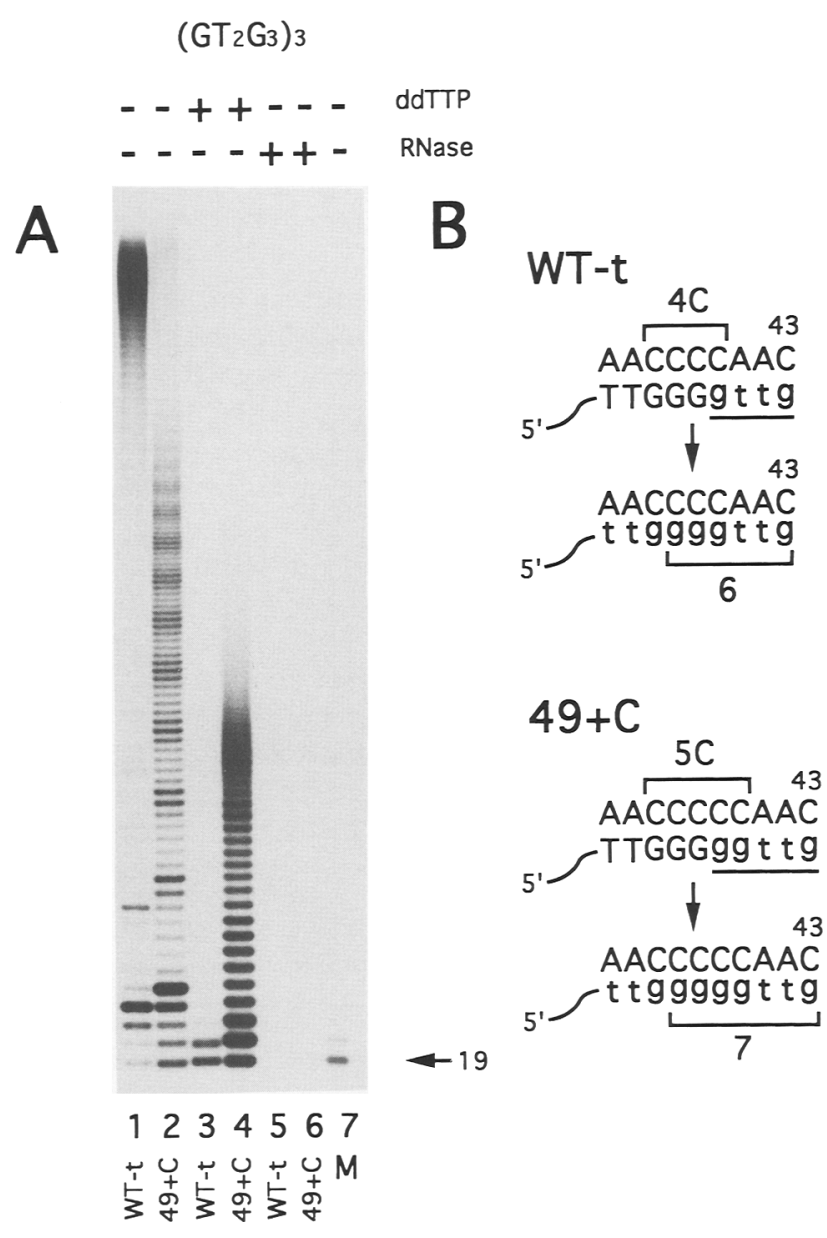

Figure 7. Expanding the template region by an additional nucleotide causes loss of enzymatic fidelity and decreased processivity. $(A)$ Telomerase reactions separated on $10 \%$ sequencing gel. All reactions contained $1.5 \mu \mathrm{M}\left[\alpha^{-}{ }^{32} \mathrm{P}\right] \mathrm{dGTP}$ and primer $\left(\mathrm{GT}_{2} \mathrm{G}_{3}\right)_{3}$. (Lanes 1,3,5) Wild-type transformed telomerase; (lanes 2,4,6) mutant $49+\mathrm{C}$ telomerase; (lane 7) marker. (Lanes $1,2,5,6)$ reactions contained $100 \mu \mathrm{M}$ TTP; (lanes 3,4 ) reactions contained $100 \mu \mathrm{M}$ ddTTP. (Lanes 5,6) enzymes were preincubated with RNase A. (B) Schematic of wild-type transformed (WT-t) and mutant $49+\mathrm{C}$ template region with $\mathrm{G}_{3}$-ending primer $\left(\mathrm{GT}_{2} \mathrm{G}_{3}\right)_{3}$ showing first and second round synthesis. Note that WT- $t$ enzyme contains $4 \mathrm{C}$ residues and $49+\mathrm{C}$ contains $5 \mathrm{C}$ residues in the templating region. Elongation products are shown in lowercase letters and underlined.

\section{Discussion}

Altering specific template RNA residues changes the enzymatic properties of telomerase

Until this work, telomerase RNA had been implicated primarily in providing a passive templating role for telomerase. However, the conserved structure of telomerase RNA has suggested that it may provide additional functions to the enzyme. To explore this issue, we have analyzed the enzymatic properties of telomerase assembled in vivo with mutated telomerase RNAs. This approach is possible because transfection of cells with the mutated telomerase RNA genes results in essentially complete substitution of the telomerase RNP with the mutated RNA. The mutations that we analyzed, all in the telomere complementary sequence $3^{\prime}$-AACCCCAAC- $5^{\prime}$, do not markedly affect the intrinsic rate of the reaction. Thus, catalysis by these mutant enzymes was not destroyed nonspecifically because of misfolding or other loss of functional integrity. However, the unexpected outcome of mutating certain telomerase RNA residues was the profound alteration of two key enzymatic properties-fidelity and interactions of the enzyme with the DNA substrate-of these mutant telomerases. We conclude that RNA template base-specific interactions, distinct from Watson-Crick pairing with the DNA primer and dNTP substrates, play critical roles in active site functions. As depicted schematically in Figure 8 , these effects are exerted even when the position being copied is not the mutated base.

\section{Enzymatic fidelity}

In contrast to cellular DNA polymerases, which have extraordinarily high fidelities, ranging from $10^{-7}$ to $10^{-11}$ errors per nucleotide, reverse transcriptases have considerably lower fidelities. Retroviral reverse transcriptases exhibit variable degrees of misincorporation with error frequencies generally in the range of $10^{-4}$ $10^{-6}$, and up to $10^{-2}$ for spleen necrosis virus (SNV) (Pathak and Temin 1990; Yu and Goodman 1992; Bebenek and Kunkel 1993). For wild-type Tetrahymena telomerase, the rarity of variant telomeric repeat sequences in wild-type cloned telomeres, the regularity of the product banding patterns on DNA sequencing gels, and the failure to observe incorporation of ${ }^{32} \mathrm{P}$ label from dATP or dCTP are consistent with error frequencies no higher than $\sim 10^{-2}$. Therefore, the high frequency of mispair synthesis and mispair extension seen with the $48 \mathrm{U}$ telomerase, and the high levels of translocated slippage by the $49+\mathrm{C}$ telomerase resulting in runs of $\sim 30 \mathrm{dG}$ residues, represent rates of these events that are unprecedented even for the error-prone reverse transcriptases and suggest that these residues play key roles in enzymatic functions of telomerase.

The $\mathrm{C} \rightarrow \mathrm{U}$ transition at residue 48 revealed that this residue plays an important role in telomerase polymerization fidelity. Although misincorporation was not detectable at residue $48 \mathrm{U}$, the mutation abolished enzyme fidelity largely at positions 47 and 46, resulting in misincorporation of $\mathrm{dA}$ residues at these positions (see Fig. 8). Fidelity of DNA polymerases has been proposed to involve in large part the recognition of strict local geometry of Watson-Crick base pairs (for review, see Johnson 1993). The most common mispairings, $\mathrm{G} / \mathrm{T}$ and $\mathrm{A} / \mathrm{C}$ pairs, allow the helix backbone geometry to be maintained and are not sufficiently different in free energy of binding from Watson-Crick base pairs to explain the low frequencies of templating fidelity errors typically observed. However, A/C and G/T mismatches violate local Watson-Crick base pair geometry (Hunter et al. 1986, 
1987). The $48 \mathrm{U}$ enzyme synthesized and extended dA/rC mispairs at high rates. Therefore, we propose that one effect of this mutation is distortion of the enzyme active site in such a way as to prevent Watson-Crick base pair discrimination. Specifically, when the $48 \mathrm{U}$ mutant telomerase is polymerizing at positions 47 and 46 , the uracil base at position 48 now allows binding of the wrong dNTP substrate, dATP, to be followed by efficient polymerization. This result implies that the wild-type cytosine base at position 48 normally interacts with the active site to disfavor misincorporation and/or favor correct incorporation. This dramatic result of such a small change $(\mathrm{C} \rightarrow \mathrm{U})$ strongly suggests that this cytosine base forms highly stereospecific contacts with active site components. We have also found that an $\mathrm{rG} / \mathrm{T}$ mispair was elongated extremely efficiently by another mutant enzyme, 49G, suggesting that position 49 also may play a similar role in telomerase (D. Gilley and E.H. Blackburn, in prep.).

We propose that the cytosine base at 48 forms part of the interacting functional groups that comprise the active site by making specific contacts with telomerase protein, other residues in the telomerase RNA, or both. The $48 \mathrm{C}$ residue is Watson-Crick base-paired with its DNA substrate, so that additional hydrogen bonding contacts are unlikely to involve the ring N3 position, whose hydrogen bonding potential is occupied. However, there are ample precedents for an RNA cytosine base in a Watson-Crick base pair forming additional specific hydrogen bonding or other contacts with protein residues. For example, in the seryl-tRNA synthetase/tR$\mathrm{NA}^{\text {Ser }}$ cocrystal a conserved tertiary G/C pair, in Watson-Crick paired form, makes specific contacts involving van der Waals interactions with amino acid side chains that can not be made by an A/U pair (Biou et al. 1994). Two of the cytosine base positions involved in the hydrogen bonds of the G/C Watson-Crick base pair, the 2-keto oxygen and the 4-amino nitrogen, have the potential to form additional hydrogen bonds while simultaneously in Watson-Crick pairing. For example, in the glutaminyl-tRNA synthetase tRNA ${ }^{\text {Gln }}$ complex (Rould et al. 1991) and the U1A protein complexed with an RNA hairpin (Oubridge et al. 1994), respectively, each position forms two hydrogen bonds with two separate

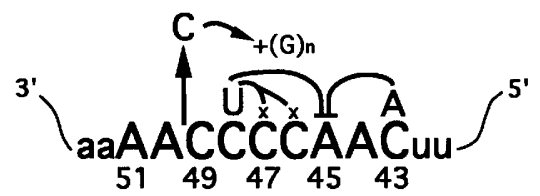

Figure 8. Effects of altering specific telomerase RNA residues on enzymatic functions. (48U) Indicated by $U$ above position 48 ; (43A) indicated by the A above position 43. Placement of an $x$ above a telomerase RNA residue indicates misincorporation at that position. The line above residue 45 represents premature dissociation at this position. $49+\mathrm{C}$ is indicated by an extra $\mathrm{C}$ residue between RNA positions 49 and $50 .+(G)_{n}$ represents synthesis of additional $\mathrm{dG}$ residues, $n=1$ to $\sim 30 \mathrm{dG}$ residues. protein functional groups. Alternatively, the WatsonCrick paired $48 \mathrm{C}$ residue has the capacity to form a base triple with another telomerase RNA residue. The $48 \mathrm{U}$ mutation could also exert its deleterious effects by the 4-keto oxygen of the uracil base acting as a new hydrogen bond acceptor in an inappropriate interaction that leads to active site distortion.

There must be relative movement between the catalytic polymerization site and the RNA template as each position along the template is copied in turn. Hence, an implication of this model, in which the RNA template forms an integral part of the active site, is that the composition of active site components will change as each position is copied along the template. Evidence suggesting that the polymerization site differs in its behavior at each position along the template comes from analysis of the effects on Tetrahymena telomerase of different chain terminating nucleoside analogs. The chain termination or competition properties of each analog was specific to each position along the template (Strahl and Blackburn 1994).

A different type of misincorporation was caused by the $49+\mathrm{C}$ insertion mutation, which expanded the $\mathrm{C}_{4}$ sequence in the templating domain to $\mathrm{C}_{5}$ and resulted in severe translocated slippage synthesis, both in vitro and in vivo. In vitro, in the presence of $100 \mu \mathrm{M}$ ddTTP and only $1.5 \mu \mathrm{M}$ dGTP, runs of up to $\sim 30 \mathrm{dG}$ residues were synthesized. The $43 \mathrm{~A}$ mutation also caused a qualitatively similar effect under these conditions, with significantly increased slippage synthesis before chain termination. The massive increase in translocated slippage by the $49+\mathrm{C}$ insertion mutant is perhaps not surprising given the strong effects of the $48 \mathrm{C} \rightarrow U$ mutation on fidelity. The additional $C$ residue added to the RNA template region would potentially cause a large distortion in the spatial relationships between template residues and other components at the active site.

\section{Premature dissociation}

A different but no less striking effect on the enzymatic action of telomerase was caused by the $43 \mathrm{~A}$ and $48 \mathrm{U}$ mutations: Premature dissociation of the elongating polymerization product, specifically at residue 45 (Fig. 8 ). With the 43A mutant telomerase, premature dissociation was confined to the first elongation round and occurred two nucleotides before the altered 5 '-terminal template nucleotide was reached at position 43 . Therefore, this effect cannot be attributed to altered base-pairing between the telomerase RNA template at position 43 and the DNA primer or product. With the $48 \mathrm{U}$ mutant telomerase, in the first and also all subsequent rounds of synthesis, there was strong product dissociation at position 45 , with what appeared to be essentially no product dissociation at position 43 . This was accompanied by a dramatic 2-base downward shift in the pattern of products relative to wild-type enzyme products. The simplest explanation for this shift is that the $48 \mathrm{U}$ mutation alters the region of telomerase RNA that functions as the template, so that after dissociation and translocation, the $\mathrm{T}$ 
copied from position 45 reanneals at position 51 , and the next rounds of elongation occur by cycles of copying residues 50-45. This would allow annealing of only $1 \mathrm{bp}$ (at position 51) and require position 50 now to be used as a templating position, although with other mutants we were unable to detect templating at this position (D. Gilley and E. Blackburn, in prep.). Alternatively, the shifted 6-base repeat pattern could result from a small fraction of products that remain associated at position 45 being elongated through to position 43 , and reannealing of the 3 ' nucleotides of the translocated product occurring as usual at position $49-51$. In this case, the $48 \mathrm{U}$ mutation would have to greatly reduce the normal dissociation at position 43 , as there is no strong band at this position. A third alternative is that the $48 \mathrm{U}$ mutant telomerase proceeds past the normal $5^{\prime}$ end of the template and copies the $U$ at position 42 , and after translocation, the GA 3' end of the elongation product anneals with the $\mathrm{CU}$ at positions 49 and 48. Each of these possible explanations for the observed shift in the six-base pattern requires a markedly altered mode of action of the $48 \mathrm{U}$ mutant enzyme during polymerization along the template.

By analogy with polymerases and reverse transcriptases (Bebenek and Kunkel 1993), telomerase may act initially on a primer in a nonprocessive mode (short abortive product formation), and a conformational change may occur when telomerase assumes the processive enzymatic mode. We propose that the active site is distorted by the $48 \mathrm{U}$ mutation in an manner that affects both nonprocessive and processive modes of synthesis, leading to dissociation after position 45 is copied. In contrast, because the $43 \mathrm{~A}$ mutant showed strong dissociation at position 45 only in the first, but not subsequent, rounds of elongation, the 43A mutation may exert its primary effect on active site function when the enzyme is in its nonprocessive initiation mode.

We propose that both the $48 \mathrm{U}$ and $43 \mathrm{~A}$ mutations cause product dissociation at position 45 by distorting the active site in such a way as to weaken the interactions between the DNA $3^{\prime}$ terminus and the enzyme specifically at this position. As discussed above for the $48 \mathrm{C} \rightarrow \mathrm{U}$ transition mutation, there are several types of base-specific interactions possible between the wild-type $43 \mathrm{C}$ and residues functionally connected to the active site. However, changing the pyrimidine $43 \mathrm{C}$ to the purine $\mathrm{A}$ has the potential for larger effects on base-specific interactions, such as the bulkier adenine base sterically blocking binding to functional groups, or introducing new interactions that alter the shape of the active site when it is at position 45 . It was proposed previously that the nascent DNA/RNA helix is unwound by displacement of the recently made DNA into a lagging product site on telomerase (Lee et al. 1993). DNA base-specific contacts with this site, distinct from the Watson-Crick base pairing with template residues, were proposed to explain the observed base-specific effects of such DNA primer residues on the catalytic rate constant of the polymerization reaction (Lee and Blackburn 1993). Therefore, another possibility is that the 43 and 48 mutations may cause premature dissociation by disrupting DNA- telomerase interactions through distortion of the lagging product site.

The results in this paper provide the first direct evidence that template residues in the RNA moiety of telomerase have distinct influences on enzyme function beyond simply passively specifying the telomeric DNA sequence. They show that specific RNA template residues have an intimate functional collaboration with the enzyme active site, to a degree unprecedented for a reverse transcriptase. Our results lead us to propose a revised view of the active site of telomerase, in which telomerase RNA residues contribute components to the network of stereospecifically interacting groups required for proper active site function.

\section{Materials and methods}

\section{Strains and transformation}

T. thermophila strains used for all experiments were CU427, ChxA/ChxA (cy-sens, VI), and CU428, Mpr/Mpr (6-mp sens, VII), kindly provided by P.J. Bruns (Cornell University, Ithaca, NY). Both strains are paromomycin sensitive and contain B rDNA. Cells were grown on $2 \%$ PPYS $(2 \%$ proteose peptone, $0.2 \%$ yeast extract, $0.003 \%$ Sequestrine) with penicillin (100 $\mu \mathrm{g} / \mathrm{ml})$, amphotericin B $(250 \mathrm{pg} / \mathrm{ml})$, and streptomycin $(100 \mu \mathrm{g} /$ $\mathrm{ml}$ and $100 \mathrm{rpm}$ shaking at $30^{\circ} \mathrm{C}$ to late logarithmic phase. Cells were starved for $\sim 24 \mathrm{hr}$, and mating types were mixed. Ten to $11 \mathrm{hr}$ after mixing, electroporation was performed essentially as described by Gaertig and Gorovsky (1992). The electroporation apparatus used was a Bio-Rad Gene Pulser set at $440 \mathrm{~V}$, $200 \mathrm{ohms}$, and $25 \mu \mathrm{F}$ with $0.4-\mathrm{cm}$ electrode gap cuvettes. The vector used for electroporation was prD4-1, which contains a recombinant rDNA allele carrying the two direct repeat replication origins from $\mathrm{C} 3$ rDNA / the first origin contains an additional $G$ residue within the rDNA promoter) and Pmr marker and downstream region from B rDNA (Yu and Blackburn 1989). Transformants were challenged with $100 \mu \mathrm{g} / \mathrm{ml}$ of paromomycin $\sim 24 \mathrm{hr}$ after electroporation. Transformants were evident 3-4 days after introduction of paromomycin.

\section{Site-directed mutagenesis}

Mutagenesis was performed by overlap extension using PCR as described previously (Ho et al. 1989) except for the following modifications. PCR was subjected to 20 cycles of denaturation $\left(30 \mathrm{sec}, 94^{\circ} \mathrm{C}\right)$, annealing $\left(30 \mathrm{sec}, 50^{\circ} \mathrm{C}\right)$, and extension $(30 \mathrm{sec}$, $72^{\circ} \mathrm{C}$ ) using conditions supplied by the manufacturer of the DNA Thermal Cycler (Perkin-Elmer Cetus). Mutant telomerase RNAs were inserted into the vector prD4-1 (Yu and Blackburn 1989 ) at the XhoI site within the vector polylinker. Potential mutant genes were carefully sequenced to detect possible unwanted errors by Taq polymerase.

\section{Telomerase preparation}

Partially purified mutant and wild-type telomerase were prepared as described previously with the following modifications (Greider and Blackburn 1987; Lee and Blackburn 1993). Populations of mutant and wild-type telomerase RNA gene transformants were cultured in $50 \mathrm{ml}$ with $100 \mathrm{rpm}$ shaking at $30^{\circ} \mathrm{C}$ to late logarithmic or, in the case of lethal mutants, to maximal populational density before complete phenotypic expression. Cells were washed once with Dryl's solution (1.7 mM sodium citrate, $2.4 \mathrm{~mm}$ sodium phosphate, $2 \mathrm{mM} \mathrm{CaCl}$ ), and incubated 
in Dryl's solution at $30^{\circ} \mathrm{C}$ with shaking at $100 \mathrm{rpm}$ for $\sim 24 \mathrm{hr}$. S100 extract was loaded onto a DEAE-agarose (Bio-Rad) column and eluted with $300 \mathrm{~mm}$ sodium acetate after washing with six column volumes of $200 \mathrm{~mm}$ sodium acetate. Preparations from the previous column were brought to $500 \mathrm{~mm}$ sodium acetate and desalted by loading on to an octyl-Sepharose (Pharmacia) column and washing with six column volumes of TMG buffer $10 \mathrm{~mm}$ Tris- $\mathrm{HCl}$ at $\mathrm{pH} 8.0,1 \mathrm{~mm} \mathrm{MgCl}_{2}, 10 \%$ glycerol, $0.1 \mathrm{~mm}$ phenylmethylsulfonyl fluoride). Telomerase was eluted with TMG containing $1 \%$ Triton $\mathrm{X}-100$ and samples were kept frozen at $-80^{\circ} \mathrm{C}$ until needed.

\section{Telomerase reactions}

Full-length primer was purified on $20 \%$ polyacrylamide- $8 \mathrm{M}$ urea gels and eluted passively with shaking at $100 \mathrm{rpm}$ overnight at $37^{\circ} \mathrm{C}$. Primer was then decontaminated by passage over Sep-Pak C-18 (Waters). Telomerase reactions were performed and prepared for electrophoresis essentially as described previously (Greider and Blackburn 1987; Lee and Blackburn 1993). Final reaction mixtures contained $50 \mathrm{~mm}$ Tris $\left(\mathrm{pH} 8.5\right.$ at $\left.25^{\circ} \mathrm{C}\right)$, $1 \mathrm{~mm}$ spermidine, and $1 \mathrm{~mm}$ dithiothreitol, $1 \mathrm{mM}$ primer, $1.5 \mu \mathrm{M}$ $\left[\alpha^{-32} \mathrm{P}\right] \mathrm{dNTP}$ (either dGTP, dATP, or TTP, where indicated), and $100 \mu \mathrm{M}$ other cold dNTPs. ddNTPs where specifically indicated were added at a final concentration of $100 \mu \mathrm{M}$. Reactions were incubated at $30^{\circ} \mathrm{C}$ for $45 \mathrm{~min}$ unless other times are specified. Elongation products from the in vitro reaction were run on $10 \%$ polyacrylamide $-8 \mathrm{M}$ urea gels. Gels were dried and exposed to $\mathrm{X}$-ray film, generally for 1 to 2 days at $-80^{\circ} \mathrm{C}$, before development.

\section{Acknowledgments}

We thank Carol Gross and our colleagues in the laboratory, Marita Cohn, Anat Krauskopf, Mike McEachern, and He Wang, for critical reading of the manuscript and for helpful suggestions. We also thank Robert Fletterick for stimulating discussions. This work was supported by a National Institutes of Health grant to E.H.B. and an American Cancer Society postdoctoral fellowship to D.G.

The publication costs of this article were defrayed in part by payment of page charges. This article must therefore be hereby marked "advertisement" in accordance with 18 USC section 1734 solely to indicate this fact.

\section{References}

Autexier, C. and C.W. Greider. 1994. Functional reconstitution of wild-type and mutant Tetrahymena telomerase. Genes \& Dev. 8: 563-575.

Bebenek, K. and T.A. Kunkel. 1993. The fidelity of retroviral reverse transcriptases. In Reverse transcriptase. led. A.M. Skalka and S.P. Goff), pp. 85-103. Cold Spring Harbor Laboratory Press, Cold Spring Harbor, New York.

Beese, L.S., V. Derbyshire, and T.A. Stertz. 1993. Structure of DNA polymerase I Klenow fragment bound to duplex DNA. Science 260: 352-355.

Biessmann, H., S.B. Carter, and J.M. Mason. 1990. Chromosome ends in Drosophila without telomeric DNA sequences. Proc. Natl. Acad. Sci. 87: 1758-1761.

Bhattacharyya, A. and E.H. Blackburn. 1994. Architecture of telomerase RNA. EMBO I. 13: 5721-5731.

Biou, V., A. Yaremchuk, M. Tukalo, and S. Cusack. 1994. The $2.9 \AA$ crystal structure of T. thermophilus seryl-tRNA synthetase complexed with tRNA ${ }^{\text {ser }}$. Science 263: 1404-1410.

Blackburn, E.H. 1992. Telomerases. Annu. Rev. Biochem. 61:
113-129.

- 1994. Telomeres: No end in sight. Cell 77: 621-623.

Cohn, M. and E.H. Blackburn. 1995. Identification of yeast telomerase activity. Science 269: 396-400.

Collins, K. and C.W. Greider. 1993. Tetrahymena telomerase catalyzes nucleolytic cleavage and nonprocessive elongation. Genes \& Dev. 7: 1364-1376.

Gaertig, J. and M.A. Gorovsky. 1992. Efficient mass transformation of Tetrahymena thermophila by electroporation of conjugants. Proc. Natl. Acad. Sci. 89: 9196-9200.

Greider, C.W. and E.H. Blackburn. 1987. The telomere terminal transferase of Tetrahymena is a ribonucleoprotein enzyme with two kinds of primer specificity. Cell 51: 887-898.

- 1989. A telomeric sequence in the RNA of Tetrahymena telomerase required for telomere repeat synthesis. Nature 337: 331-337.

Ho, S.N., H.D. Hunt, R.M. Horton, J.K. Pullen, and L.R. Pease. 1989. Site-directed mutagenesis by overlap extension using the polymerase chain reaction. Gene 77: 51-59.

Hunter, W.N., T. Brown, N.N. Anand, and O. Kennard. 1986. Structure of an adenine-cytosine base pair in DNA and its implications for mismatch repair. Nature 320: 552-555.

Hunter, W.N., T. Brown, G. Kneale, N.N. Anand, D. Rabinovich, and O. Kennard. 1987. The structure of guanosine-thymidine mismatches in B-DNA at $2.5-\AA \AA$ resolution. I. Biol. Chem. 262: 9962-9970.

Johnson, K.A. 1993. Conformational coupling in DNA polymerase fidelity. Annu. Rev. Biochem. 62: 685-713.

Lee, M.S. and E.H. Blackburn. 1993. Sequence-specific DNA primer effects on telomerase polymerization activity. Mol. Cell. Biol. 13: 6586-6599.

Lee, M.S., R.C. Gallagher, J. Bradley, and E.H. Blackburn. 1993. In vivo and in vitro studies of telomeres and telomerase. Cold Spring Harbor Symp. Quant. Biol. 58: 707-718.

Levis, R.W., R. Ganesan, K. Houtchens, L.A. Tolar, and F.-M. Sheen. 1993. Transposons in place of telomeric repeats at a Drosophila telomere. Cell 75: 1083-1093.

Lingner, J., L.L. Hendrick, and T.R. Cech. 1994. Telomerase RNAs of different ciliates have a common secondary structure and a permuted template. Genes \& Dev. 8: 1984-1998.

Mantell, L.L. and C.W. Greider. 1994. Telomerase activity in germline and embryonic cells of Xenopus. EMBO J. 13: 3211-3217

Oubridge, C., N. Ito, P.R. Evans, C.-H. Teo, and K. Nagai. 1994. Crytstal structure at $1.92 \AA$ resolution of the RNA-binding domain of the U1A spliceosomal protein complexed with an RNA hairpin. Nature 372: 432-438.

Pathak, V.K. and H.M. Temin. 1990. Broad spectrum of in vivo forward mutations, hypermutations, and mutational hotspots in a retroviral shuttle vector after a single replication cycle: Substitutions, frameshifts, and hypermutations. Proc. Natl. Acad. Sci. 87: 6019-6023.

Prowse, K.R., A.A. Avilion, and C.W. Greider. 1993. Identification of a nonprocessive telomerase activity from mouse cell. Proc. Natl. Acad. Sci. 90: 1493-1497.

Romero, D.P. and E.H. Blackburn. 1991. A conserved secondary structure for telomerase RNA. Cell 67: 343-353.

1995. Circular rDNA replicons persist in Tetrahymena thermophila transformants synthesizing GGGGTC telomeric repeats. I. Euk. Microbiol. 42: 32-43.

Rould, M.A., J.J. Perona, and T.A. Steitz. 1991. Structural basis of anticodon loop recognition by glutaminyl-tRNA synthetase. Nature 352: 213-218.

Shippen-Lentz, D. and E.H. Blackburn. 1990. Functional evidence for an RNA template in telomerase. Science 247: 546552. 
Gilley et al.

Strahl, C. and E.H. Blackburn. 1994. The effects of nucleoside analogs on telomerase and telomeres in Tetrahymena. $\mathrm{Nu}$ cleic Acids Res. 22: 893-900.

ten Dam, E., A. van Belkum, and K. Pleij. 1991. A conserved pseudoknot in telomerase RNA. Nucleic Acids Res. 19: 6951.

Watson, J.D. 1972. Origin of concatameric T4 DNA. Nature New Biol. 239: 197-201.

Yu, G.-L. and E.H. Blackburn. 1989. Transformation of Tetrahymena thermophila with a mutated circular ribosomal DNA plasmid vector. Proc. Nat1. Acad. Sci. 86: 8487-8491.

1991. Developmentally programmed healing of chromosomes by telomerase in Tetrahymena. Cell 67: 823-832.

Yu, H. and M.F. Goodman. 1992. Comparison of HIV-1 and avian myelobastosis virus reverse transcriptase fidelity on RNA and DNA templates. J. Biol. Chem. 267: 10888-10896.

Yu, G.-L., J.D. Bradley, L.D. Attardi, and E.H. Blackburn. 1990. In vivo alteration of telomere sequences and senescence caused by mutated Tetrahymena telomerase RNAs. Nature 344: 126-132.

Zakian, V.A. 1989. Structure and functions of telomeres. Annu. Rev. Genet. 23: 579-604. 


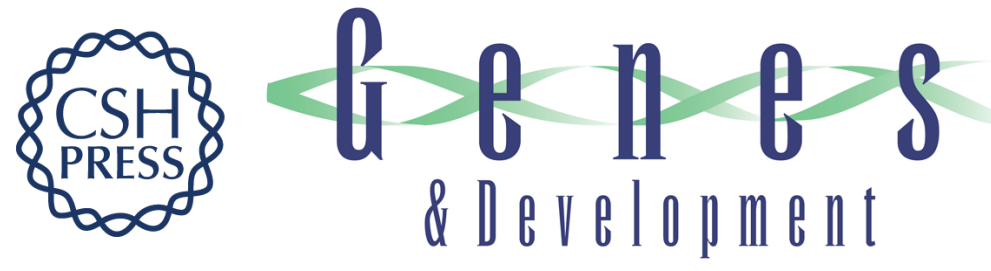

\section{Altering specific telomerase RNA template residues affects active site function.}

D Gilley, M S Lee and E H Blackburn

Genes Dev. 1995, 9:

Access the most recent version at doi:10.1101/gad.9.18.2214

References This article cites 36 articles, 16 of which can be accessed free at:

http://genesdev.cshlp.org/content/9/18/2214.full.html\#ref-list-1

License

Email Alerting

Service

Receive free email alerts when new articles cite this article - sign up in the box at the top right corner of the article or click here.

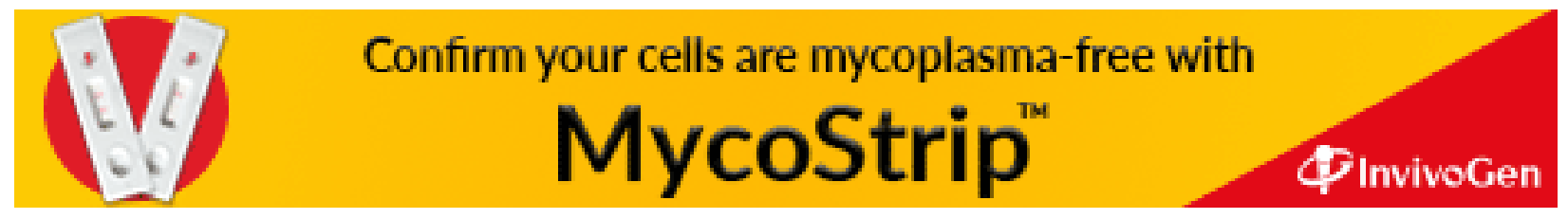

